\title{
Comparative Study of the Biotypes of Busuioaca de Bohotin Variety from Husi Vineyard
}

\author{
Alexandru C. TARTIAN ${ }^{1 *}$, Cintia COLIBABA ${ }^{1}$, Marius NICULAUA ${ }^{2}$, Bogdan C-tin NECHITA ${ }^{1}$, Cătălin \\ ZAMFIR $^{1}$, Ana- Maria MOROŞANU ${ }^{1}$, Valeriu V. COTEA ${ }^{1}$ \\ ${ }^{1}$ Faculty of Horticulture, University of Agricultural Studies and Veterinary Medicine Iasi, Romania \\ ${ }^{2}$ Oenological Research Center- Romanian Academy- Iasi Branch \\ *)corresponding author, e-mail: artianalexandru@gmail.com
}

BulletinUASVM Horticulture 72(2) / 2015

Print ISSN 1843-5254, Electronic ISSN 1843-5394

DOI:10.15835/buasvmcn-hort:11461

\begin{abstract}
Busuioacă de Bohotin grapes were harvested at technological maturity in 2014, both biotypes (dark violet biotype and rose biotype) being from Huşi vineyard. The wines were obtained by applying four types of maceration processes: maceration-fermentation, microwave maceration, ultrasound maceration and cryomaceration, namely: Vo-control sample (no yeast and enzymes), V1- Maceration-fermentation, V2-Microwave maceration, V3Ultrasound maceration and V4-Cryomaceration. The wine samples obtained were characterized from a physicochemical and sensorial point of view, the main objective of the study being to compare the dark violet biotype and rose biotype of the Busuioacă de Bohotin variety. The physico-chemical analyses were done according to the Compendium of International Methods of Analysis of Wine and Musts (OIV, 2013).The sensory evaluation was conducted according the evaluation method originally proposed by the International Union of Oenologists (UIO). The obtained wines are dry wines with a reducing sugar content between $1.84 \mathrm{~g} / \mathrm{l}$ (minimum) for dark violet biotype (V2 sample) and $2.18 \mathrm{~g} / \mathrm{l}$ (maximum) for rose biotype (V1 sample). In terms of alcohol concentration, the highest values were recorded at the dark violet biotype with a maximum of $14.9 \%$ vol. and a minimum of 13.91 $\%$ for rose biotype. Sensory analyses revealed that the highest intensity of flavours had the dark violet biotype of Busuioacă de Bohotin variety. It was observed that there were found major differences between the two biotypes of Busuioacă de Bohotin variety on physico-chemical and sensory characteristics, the highest value for all the characteristics being recorded by the dark violet biotype.
\end{abstract}

Keywords: Busuioacă de Bohotin, cryomaceration, microwaves, ultrasounds, physico-chemical \&sensorial analysis.

\section{INTRODUCTION}

Wine's aromatic profile depends on the grape sort, maturity degree at harvest, yeast activity, prefermentative procedures and aging (Cotea et al., 1985, 1988). A special place among rose Romanian wines is occupied by Busuioacă de Bohotin, that can easily rival cosmopolitan varieties not only through its phenolic quality but also through its aroma (Vărăticeanu Gh. et al., 1998).

Busuioacă de Bohotin variety is the most popular aromatic variety from Romania and it is characterized by a distinct aroma dominated by shades of rose, basilica, coriander.
Currently it occupies a small area crop due to some factors: the age and genetic erosion, the interaction between genotype and environmental and vegetative propagation, appearing as a heterogeneous population, with various biotypes that differ from a phenotypical, agrobiological and technological point of view. (Rotaru et al., 2011)

From a visual point of view, the differences between rose biotype and dark violet biotype consists in the color of the berries, the rose biotype being much brighter than the dark violet biotype but darker than the Muscat Rouge Frontignan 
variety from which is closely related to. Both biotypes have the pulp uncolored.

Wine's aroma is given mainly by the terpenic compounds that accumulate in skin grapes (varietal aromas), secondary aromas that are formed during alcoholic fermentation and the aromas rezulted during aging that forms the bouquet of the wine. The varietal aromas gives wine the tipicity of the variety used and imprints wines authenticity. To extract the flavors from grapes it is necessary a maceration process.

Maceration is responsible for all of the specific characteristics of sight, smell and taste that differentiate red wines from white wines. Phenolic compounds (anthocyanins and tannins) are primarily extracted, participating in the color and overall structure of wine. Yet aromas and aroma precursors, nitrogen compounds, polysaccharides (in particular, pectins) and minerals are also liberated in the must or wine during maceration. The maceration process should be modulated in a way that only useful grape constituents should be dissolved-those positively contributing to wine flavor and aroma. So, the extraction of these desirable substances should be maximal, if not total (Ribereau Gayon et al., 2006).

The main objective of the present study is to evaluate the differences between rose biotype and dark violet biotype of Busuioacă de Bohotin variety on the physico-chemical and sensorial characteristics of the analysed wines.

\section{MATERIALS AND METHODS}

Busuioacă de Bohotin grapes were harvested at technological maturity in 2014, both biotypes (dark violet biotype and rose biotype) being from Huşi vineyard.

For obtaining the wines taken in this study it was used the specific technology for aromatic wines, therefore it was applied a maceration operation. Four types of maceration processes were applied for all the biotypes studied. The maceration time for all the processes it was seven days and it was added yeast- Fermactive Rouge Primeur (10-20 g/hl pomace) and pectolitic enzyme-Zymovarietal Aroma G (2-3 g/hl pomace) both from Sodinal company.

V0-Control sample- for this type of maceration the grapes were crushed, destemmed and the pomace obtained it was introduced in plastic cans with cap. For this variant of maceration it was not added yeast and enzymes.

V1-Maceration fermentation- the technology that was applied for this type of maceration it is similar with the control sample, with the difference that was added yeast and enzymes.

V2-Microwave maceration- the obtained pomace was irradiated with microwaves at a power of $750 \mathrm{~W}$ for 15 minutes (Whirlpool microwave oven, model JT358/WH). Meanwhile, the pomace was homogenized from 3 in 3 minutes to equally heat the pomace.

V3-Ultrasound maceration- was performed in an ultrasonic bath Bandelin Sonorex, model RK 1028 (35 kHz frequency, $2000 \mathrm{~W}$ power) for 30 minutes. Due to specific ultrasound cavitation phenomenon, grape cell walls were destroyed, thus favored cellular juice extraction.

V4-Cryomaceration-was carried out in a freezer, where the whole grapes were subjected to a temperature of $-20^{\circ} \mathrm{C}$ for 24 hours. After freezing the grapes, they were manually destemmed and after finishing the crushing operation they were submitted to the maceration process.

After 7 days of maceration the pomace was pressed using a hydraulic press and the completion of the alcoholic fermentation was carried out in glass vessels. After alcoholic fermentation, the wines were pumped over, filtered, sulfured and bottled. The obtained wines were analyzed from a physico-chemical and sensorial point of view.

The physico-chemical analyses were done according to the Compendium of International Methods of Analysis of Wine and Musts (OIV, 2013) and there were determinated the following parameters: sulfur dioxide, volatile acidity, total acidity, alcoholic strength, density, total dry matter and non-reducing substances, $\mathrm{pH}$ and conductivity.

The sensory evaluation was conducted according to the evaluation method originally proposed by the International Union of Oenologists (UIO) and consists in granting a certain score for each sensory feature of the wine after a "closed" taste. After data centralization a graphic representation of the sensory characteristics for the analyzed wines was obtained.

\section{RESULTS AND DISCUSSION}

Analyzing the data from the table 1 , it was observed a higher variability concerning total acidity. The lowest value of acidity was registred by 
V4 Cryomaceration sample with $3.88 \mathrm{~g} / \mathrm{l}$ tartaric acid, in comparison with the control sample 5.23 $\mathrm{g} / \mathrm{l}$, the maximum being reached by V2 Microwave maceration with $5.84 \mathrm{~g} / \mathrm{l}$.

In terms of alcoholic concentration, all the samples showed high values, over $14 \%$ alc. conc., the maximum being recorded by the V4Cryomaceration sample with $14.90 \%$ alc. conc. Analyzing T.D.E (total dry extract) and N.E (nonreductive extract) parameters it was observed that all the samples have high values, with a maximum of $26.3 \mathrm{~g} / \mathrm{L}$ T.D.E and $24.14 \mathrm{~g} / \mathrm{L}$ N.E. for the V3Ultrasound maceration sample, the minimum being recorded by the control sample V0.

For the rose biotype of Busuioacă de Bohotin variety, doesn't exists wide variations on the physico-chemical parameters for the maceration variants applied. The total acidity has an average value of $5.70 \mathrm{~g} / \mathrm{l}$ tartaric acid, the maximum being reached by the control sample- V0 with $6.28 \mathrm{~g} / \mathrm{l}$ tartaric acid and refeer to alcoholic concentration, the average value obtained was $14.19 \%$.

Comparing the two biotypes of the Busuioacă de Bohotin variety from a physico-chemical point of view, it is observed that the highest value of total acidity was recorded by the rose biotype with a value of $6.18 \mathrm{~g} / \mathrm{l}$ tartaric acid for the control sample V0, the minimum being recorded by the V4-Cryomaceration sample of the dark violet biotype with $3.18 \mathrm{~g} / \mathrm{l}$.

The maximum alcoholic concentration was reached by sample $\mathrm{V} 4$ of the dark violet biotype with a value of $14.9 \%$ alc.

Also, the highest values of T.D.E and N.E were reached by the same biotype, for V3-Ultrasound maceration sample with $26.3 \mathrm{~g} / \mathrm{L}$ T.D.E and 24.14 g/L N.E.

Reducing sugars content for all the samples of both biotypes presented similar values, with an average of $2.02 \mathrm{~g} / \mathrm{l}$, therefore they all fall into the category of dry wines.

$\mathrm{pH}$ parameter has reached high values with an average of 3.80 for all analyzed wines samples. Elevated $\mathrm{pH}$ values may be due to the low total acidity recorded by this samples.

Also, the wine conductivity for all samples, showed high values, above $2 \mathrm{mS} / \mathrm{cm}$, emphasing their high level of ionization.

As it can be seen from table 3 , the sulfur dioxide and volatile acidity parameters are within the normal limits for all the analyzed wine samples.

Tab.1. Physico-chemical analysis of the Dark violet biotype.

\begin{tabular}{ccccccccc}
\hline Analized wines & $\begin{array}{c}\text { Total } \\
\text { Acidity } \\
(\mathrm{g} / \mathrm{L} \\
\left.\mathrm{C}_{4} \mathrm{H}_{6} \mathrm{O}_{6}\right)\end{array}$ & $\begin{array}{c}\text { Relative } \\
\text { Density }\end{array}$ & $\begin{array}{c}\text { Alch. } \\
\text { conc. }(\%) \\
\text { vol.) }\end{array}$ & $\begin{array}{c}\text { Reductive } \\
\text { subst. }(\mathrm{g} / \mathrm{L})\end{array}$ & $\begin{array}{c}\text { T.D.E } \\
(\mathrm{g} / \mathrm{L})\end{array}$ & $\begin{array}{c}\mathrm{N} . \mathrm{E} \\
(\mathrm{g} / \mathrm{L})\end{array}$ & $\mathrm{pH}$ & $\begin{array}{c}\text { Conductivity } \\
(\mathrm{mS} / \mathrm{cm})\end{array}$ \\
\hline Dark violet biotype V0 & 5.23 & 0.9905 & 14.75 & 2.14 & 24.5 & 22.36 & 3.87 & 2.29 \\
\hline Dark violet biotype V1 & 5.30 & 0.9906 & 14.85 & 2.14 & 25 & 22.86 & 3.88 & 2.37 \\
\hline Dark violet biotype V2 & 5.84 & 0.9908 & 14.61 & 1.84 & 24.8 & 22.96 & 3.90 & 2.39 \\
\hline Dark violet biotype V3 & 4.14 & 0.9912 & 14.73 & 2.16 & 26.3 & 24.14 & 3.92 & 2.46 \\
\hline Dark violet biotype V4 & 3.88 & 0.9905 & 14.90 & 1.87 & 25 & 23.13 & 3.86 & 2.20 \\
\hline
\end{tabular}

Tab.2. Physico-chemical analysis of the Rose biotype.

\begin{tabular}{ccccccccc}
\hline Analized wines & $\begin{array}{c}\text { Total } \\
\text { Acidity } \\
\text { (g/L } \\
\mathrm{C}_{4} \mathrm{H}_{6} \mathrm{O}_{6} \text { ) }\end{array}$ & $\begin{array}{c}\text { Relative } \\
\text { Density }\end{array}$ & $\begin{array}{c}\text { Alch. } \\
\text { conc. } \% \\
\text { vol.) }\end{array}$ & $\begin{array}{c}\text { Reductive } \\
\text { subst. (g/L) }\end{array}$ & $\begin{array}{c}\text { T.D.E } \\
\text { (g/L) }\end{array}$ & $\begin{array}{c}\text { N.E } \\
\text { (g/L) }\end{array}$ & pH & $\begin{array}{c}\text { Conductivity } \\
\text { (mS/cm) }\end{array}$ \\
\hline Rose biotype V0 & 6.28 & 0.9908 & 14.12 & 1.99 & 23.5 & 21.51 & 3.76 & 2.41 \\
\hline Rose biotype V1 & 5.84 & 0.9904 & 14.31 & 2.18 & 22.9 & 20.72 & 3.80 & 2.37 \\
\hline Rose biotype V2 & 5.84 & 0.9912 & 14.41 & 2.12 & 25.3 & 23.18 & 3.84 & 2.40 \\
\hline Rose biotype V3 & 5.45 & 0.9903 & 13.91 & 1.97 & 21.6 & 19.63 & 3.77 & 2.28 \\
\hline Rose biotype V4 & 5.40 & 0.9901 & 14.23 & 1.86 & 21.9 & 20.04 & 3.78 & 2.30 \\
\hline
\end{tabular}


Tab. 3. Sulf Dioxide and Volatile acidity of the analized wines

\begin{tabular}{cccc}
\hline \multirow{2}{*}{ Analized wines } & \multicolumn{2}{c}{$\mathrm{SO}_{2} \mathrm{mg} / \mathrm{L}$} & \multirow{2}{*}{$\begin{array}{c}\text { Volatile acidity } \\
\left(\mathrm{g} / \mathrm{L} \mathrm{C}_{2} \mathrm{H}_{4} \mathrm{H}_{2}\right)\end{array}$} \\
\cline { 2 - 3 } & Free & Total & 0.35 \\
\hline Dark violet biotype V0 & 50.78 & 147.09 & 0.36 \\
\hline Dark violet biotype V1 & 43.66 & 134.70 & 0.31 \\
\hline Dark violet biotype V2 & 31.89 & 117,36 & 0.39 \\
\hline Dark violet biotype V3 & 32.20 & 119.22 & 0.25 \\
\hline Dark violet biotype V4 & 34.68 & 124.49 & 0.37 \\
\hline Rose biotype V0 & 36.23 & 121.08 & 0.35 \\
\hline Rose biotype V1 & 43.04 & 133.47 & 0.37 \\
\hline Rose biotype V2 & 35.92 & 129.13 & 0.31 \\
\hline Rose biotype V3 & 14.83 & 70.54 & 0.33 \\
\hline Rose biotype V4 & 25.11 & 93.59 &
\end{tabular}

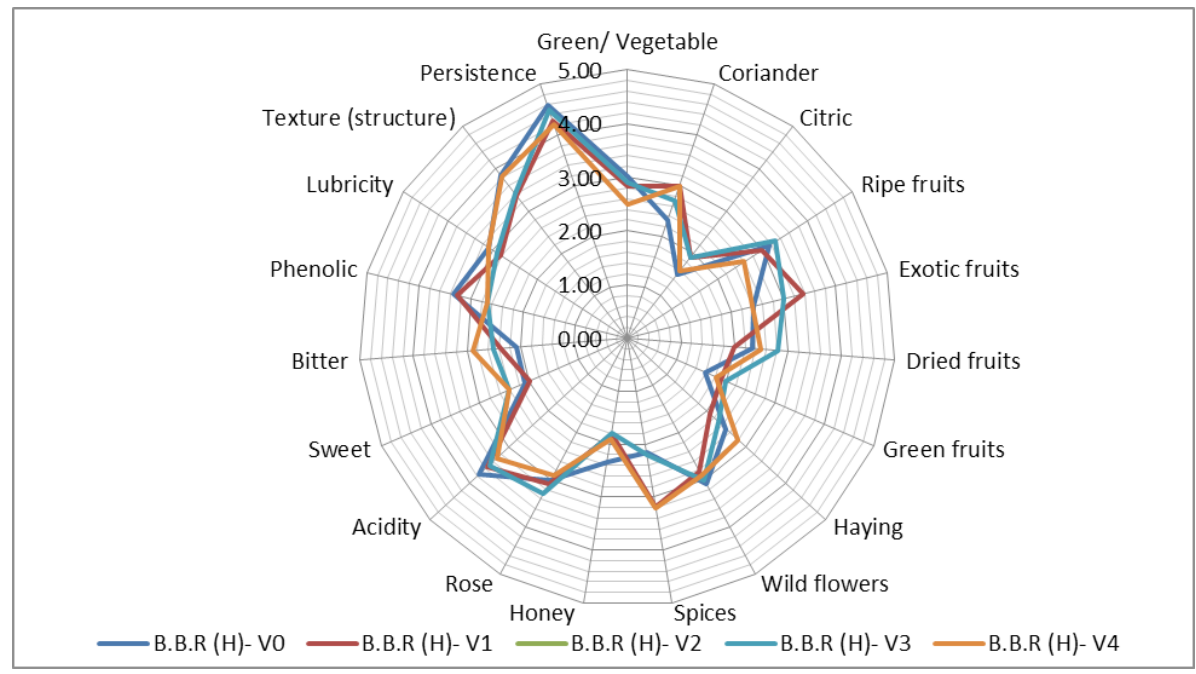

Fig. 1. The chart of sensoryal features for Rose biotype.

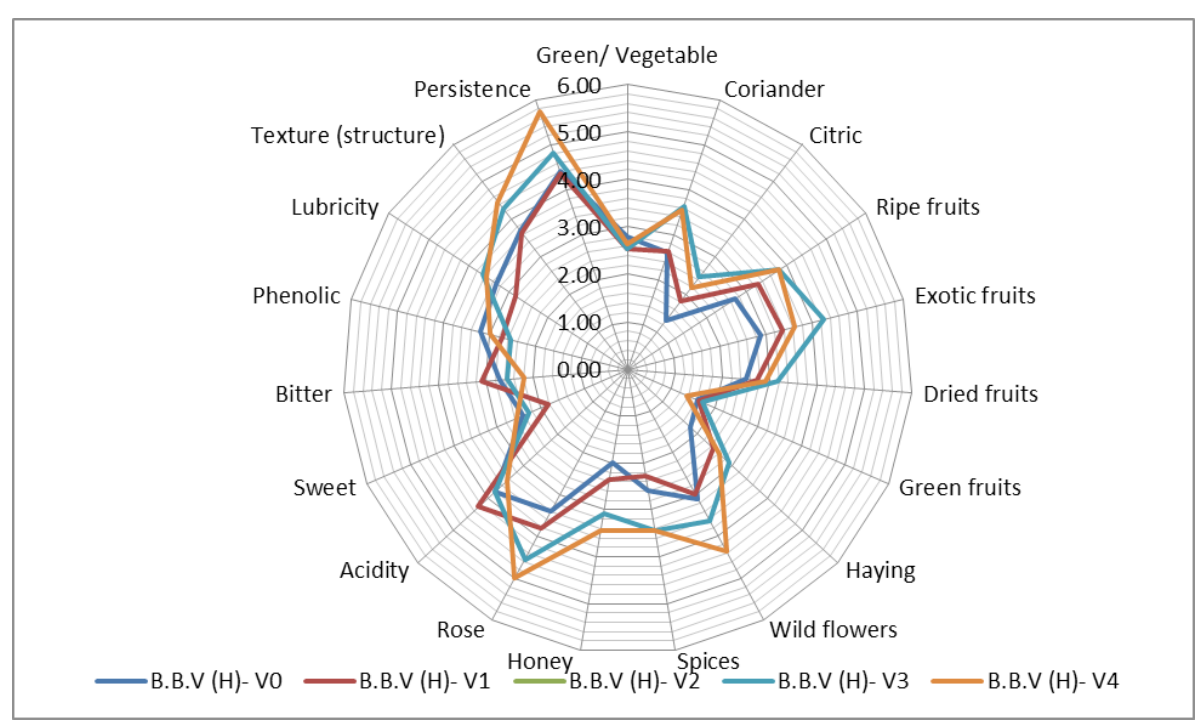

Fig.2. The chart of sensoryal features for the Dark violet biotype. 
Analyzing the chart of sensorial features for rose biotype, was observed that there aren't significant differences concerning gustative and olfactive sensations between the variants of maceration used for this biotype.

However, from figure 2, it can be seen that for the dark violet biotype the highest score for sensoryal features was obtained by V3-Ultrasound maceration and V4-Cryomaceration samples, while the controle sample had the lowest score.

Comparing the two biotypes of the Busuioacă de Bohotin variety from a sensorial point of view it was highlighted some differences.

Thus, it was revealed that $V 3$ sample of the dark violet biotype has better expressed the flavours of coriander, citrus, exotic fruits, haying, spices and the sensation of lubricity is more pronounced.

Also, aromas of rose, wild flowers and honey and sweet taste, texture and persistence are better expressed by the V4 sample of the dark violet biotype.

Regarding the rose biotype, he got bigger values for acidity, ripe fruits and vegetals features. These taste sensations are due to slightly higher values of total acidity recorded by this biotype.

It also can be seen that the highest score in terms of sensory features was obtained by the samples in which there were added enzymes and yeasts, thus favoring the release of varietal aromas of the Busuioacă de Bohotin variety.

In order to highlight the differences between the biotypes on the physico-chemical characteristics of the wine samples obtained it was conducted a paired t-test. The statistical test was applied on two grups: group A being the dark violet biotype and group B rose biotype, both biotypes being subjected to four types of maceration (V0, $\mathrm{V} 1, \mathrm{~V} 2, \mathrm{~V} 3, \mathrm{~V} 4)$. For each pair of groups (V0v : V0r, V1v : V1r, V2v : V2r, V3v : V3r, V4v : V4r) was considered as a general hypothesis: that the biotype used for the maceration processes applied had an important impact on the physico-chemical characteristics of the wine samples obtained.

Analyzing table 4 it can be seen that the value of $P$ (significance) is higher than 0.05 for all the pairs of groups, so it can be said from a statistical point of view that the biotypes used for obtaining the analyzed wine samples had no significant influence on the physico-chemical characteristics.

\section{CONCLUSIONS}

There weren't found significant differences between the values obtained after physicochemical and sensorial analysis for the maceration types applied on the same biotype. Thus, we can say that in this experiment the applied variants

Tab.4. Statistical analysis (t-test) for the analyzed wine samples.

\begin{tabular}{|c|c|c|c|c|c|c|c|c|c|c|}
\hline Group & \multicolumn{2}{|c|}{ V0v : V0r } & \multicolumn{2}{|c|}{ V1v : V1r } & \multicolumn{2}{|c|}{$\mathrm{V} 2 \mathrm{v}: \mathrm{V} 2 \mathrm{r}$} & \multicolumn{2}{|c|}{ V3v : V3r } & \multicolumn{2}{|c|}{$\mathrm{V} 4 \mathrm{v}: \mathrm{V} 4 \mathrm{r}$} \\
\hline $\mathrm{P}$ (significance) & \multicolumn{2}{|c|}{0.4219} & \multicolumn{2}{|c|}{0.1817} & \multicolumn{2}{|c|}{0.9850} & \multicolumn{2}{|c|}{0.8106} & \multicolumn{2}{|c|}{0.8884} \\
\hline $\mathrm{t}$ & \multicolumn{2}{|c|}{0.8530} & \multicolumn{2}{|c|}{1.4828} & \multicolumn{2}{|c|}{0.0191} & \multicolumn{2}{|c|}{0.2443} & \multicolumn{2}{|c|}{0.1429} \\
\hline Df & \multicolumn{2}{|c|}{7} & \multicolumn{2}{|c|}{7} & \multicolumn{2}{|c|}{14} & \multicolumn{2}{|c|}{14} & \multicolumn{2}{|c|}{14} \\
\hline $\begin{array}{l}\text { Standard error of } \\
\text { difference }\end{array}$ & \multicolumn{2}{|c|}{0.230} & \multicolumn{2}{|c|}{0.361} & \multicolumn{2}{|c|}{4.911} & \multicolumn{2}{|c|}{4.729} & \multicolumn{2}{|c|}{4.664} \\
\hline \multirow{2}{*}{ Mean } & V0v & V0r & V1v & V1r & $\mathrm{V} 2 \mathrm{v}$ & $\mathrm{V} 2 \mathrm{r}$ & V3v & $\mathrm{V} 3 \mathrm{r}$ & $\mathrm{V} 4 \mathrm{v}$ & $\mathrm{V} 4 \mathrm{r}$ \\
\hline & 9.516 & 9.320 & 9.673 & 9.138 & 9.666 & 9.760 & 9.855 & 8.700 & 9.478 & 8.812 \\
\hline \multirow{2}{*}{$\begin{array}{l}\text { SD (standard } \\
\text { deviation) }\end{array}$} & V0v & V0r & V1v & V1r & $\mathrm{V} 2 \mathrm{v}$ & V2r & V3v & V3r & $\mathrm{V} 4 \mathrm{v}$ & $\mathrm{V} 4 \mathrm{r}$ \\
\hline & 9.609 & 9.131 & 9.810 & 8.866 & 9.765 & 9.878 & 10.410 & 8.399 & 10.017 & 8.582 \\
\hline \multirow{2}{*}{$\begin{array}{l}\text { SEM (standard error } \\
\text { of the mean ) }\end{array}$} & $\mathrm{V} 0 \mathrm{v}$ & V0r & V1v & V1r & $\mathrm{V} 2 \mathrm{v}$ & V2r & V3v & V3r & $\mathrm{V} 4 \mathrm{v}$ & $\mathrm{V} 4 \mathrm{r}$ \\
\hline & 3.397 & 3.228 & 3.468 & 3.134 & 3.452 & 3.492 & 3.680 & 2.969 & 3.541 & 3.034 \\
\hline \multirow{2}{*}{$\begin{array}{c}\mathrm{N} \text { (number of } \\
\text { subjects) }\end{array}$} & V0v & V0r & $\mathrm{V} 1 \mathrm{v}$ & V1r & $\mathrm{V} 2 \mathrm{v}$ & $\mathrm{V} 2 \mathrm{r}$ & $\mathrm{V} 3 \mathrm{v}$ & $\mathrm{V} 3 \mathrm{r}$ & $\mathrm{V} 4 \mathrm{v}$ & $\mathrm{V} 4 \mathrm{r}$ \\
\hline & 8 & 8 & 8 & 8 & 8 & 8 & 8 & 8 & 8 & 8 \\
\hline Mean $V_{a}$ - Mean $V_{b}$ & \multicolumn{2}{|c|}{0.196} & \multicolumn{2}{|c|}{0.535} & \multicolumn{2}{|c|}{-0.093} & \multicolumn{2}{|c|}{1.155} & \multicolumn{2}{|c|}{0.666} \\
\hline $\begin{array}{c}\text { Confidence interval } \\
(\%)\end{array}$ & \multicolumn{2}{|c|}{95} & \multicolumn{2}{|c|}{95} & & & 9 & & c & \\
\hline
\end{tabular}


of maceration had no significant influence on the results.

After comparing the two biotypes of Busuioacă de Bohotin variety it was revealed that in the case of physico-chemical parameters were obtained better values regarding alcohol concentration, total dry matter and non-reducing substances for the dark violet biotype.

In what concerns the analysis of sensory attributes of the two biotypes, it was seen quite clearly that the primary aromas of rose and coriander that are typical for Busuioacă de Bohotin variety were much better expressed by the dark violet biotype in contrast with the rose biotype.

Therefore, it was observed that there are major differences between the two biotypes of Busuioacă de Bohotin variety on physico-chemical and sensory characteristics, the highest value for all the characteristics being recorded by the dark violet biotype.

\section{REFERENCES}

1. Cotea VD (1985). Oenology treaty (in Romanian), vol.I, Wine-making and biochemistry of wine, Ed. Ceres, București, Romania.

2. Rotaru L, Stoleru V, Petrea G (2011). Agrobiological and technological value of Busioacă de Bohotin grapevine variety in ecosystem of IASI Vineyard. Analele Universității din Craiova, seria Agricultură - Montanologie - Cadastru Vol. XLI 2011/1.

3. Varaticeanu Gh, Ivascu M, Puscas A (1998). Research on quality parameters and composition of Bohotin Busuioaca wine obtained in terms of Pietroasa. Rev. Hortiinform 9: 38-39.

4. Ribereau-Gayon P, Dubourdieu D, Doneche B, Lonvaud A (2006a). Handbook of enology. Vol. 1: The microbiology of wine and vinifications. 2nd ed. - Chichester: Wiley, 2006; 